\title{
Simulation of rumen fermentation kinetics of by-products from the biodiesel industry with in vitro gas production technique
}

\author{
Simulação da cinética de fermentação ruminal de subprodutos da \\ indústria do biodiesel através da técnica de produção de gases in vitro
}

\author{
Alex Lopes da Silva ${ }^{1 *}$; Marcos Inácio Marcondes ${ }^{2}$; Cristina Mattos Veloso ${ }^{2}$; \\ Fernanda Campos de Sousa ${ }^{3}$; Leonardo Sidney Knupp ${ }^{4}$
}

\begin{abstract}
The objective of this study was to investigate the rumen fermentation kinetics of 18 by-products from the biodiesel industry exhibiting potential for use in the feeding of ruminants via the in vitro gas production technique. The following feeds were investigated: cottonseed, canudo de pito, crambe, sunflower, castor seed (detoxified with lime) and soybean meals and cottonseed, peanut, babassu, crambe, palm kernel, sunflower, licuri nut, macaúba, forage radish and jatropha cakes. The evaluated parameters were total gas production (VfT), gas production from fibrous carbohydrates (VfFC), gas production from nonfibrous carbohydrates (VfNFC), the degradation rate of fibrous carbohydrates (kdFC), the degradation rate of non-fibrous carbohydrates (kdNFC) and lag time (lag). The feeds were grouped into six different groups according to rumen fermentation kinetic parameters and adopting an $\mathrm{R}^{2}$ of 0.8 . Forage radish cake and the meals of cottonseed, soybean, crambe and sunflower composed the first group, while the cakes of babassu and sunflower formed the second group. Canudo de pito and castor seed meals and the cakes of cottonseed, licuri and jatropha I and II formed the third group. The fourth group was composed by the cakes of crambe, palm kernel and peanut I. The fifth group was formed by peanut cake II, while macauba fruit cake formed the sixth group. The VfNFC and VfFC varied from 16.72 to $200.07 \mathrm{~mL}$ and from 53.09 to $242.12 \mathrm{~mL}$, respectively. The mean $\mathrm{kdFC}$ and $\mathrm{kdNFC}$ values varied from 0.002 to $0.039 \%$ $\mathrm{h}^{-1}$ and from 0.022 to $0.430 \% \mathrm{~h}^{-1}$, respectively. The mean lag and VfT varied from 0.0001 to 5.2029 hours and 136.94 to $301.44 \mathrm{~mL}$, respectively. A number of the products exhibited the potential to replace soybean meal, especially the forage radish cake and cottonseed, crambe and sunflower meals.
\end{abstract}

Key words: Degradation rate, fibrous carbohydrates, non-fibrous carbohydrates, ruminants

\section{Resumo}

Objetivou-se estudar a cinética de fermentação ruminal de 18 coprodutos da indústria do biodiesel, com potencial de uso na alimentação de ruminantes, através da técnica de produção de gases in vitro. Os alimentos estudados foram os farelos de: algodão, canudo de pito, crambe, girassol, mamona destoxificado com cal e soja e as tortas de: algodão, amendoim, babaçu, crambe, dendê, girassol, licuri, sementes de macaúba, nabo forrageiro e pinhão manso. Os parâmetros avaliados foram: produção total de gases (VFT), produção de gases proveniente dos carboidratos fibrosos (VFCF), produção de gases proveniente dos carboidratos não fibrosos (VFCNF), taxa de degradação dos carboidratos fibrosos (kdCF), taxa de

\footnotetext{
1 Discente de Doutorado, Dept ${ }^{\circ}$ de Zootecnia, Universidade Federal de Viçosa, UFV, Viçosa, MG, Brasil. E-mail: alex.lopes@ufv.br

2 Profs. Adjuntos, Dept ${ }^{\circ}$ de Zootecnia, UFV, Viçosa, MG, Brasil. E-mail: marcos.marcondes@ufv.br; cristina.veloso@ufv.br

3 Discente de Doutorado, Dept ${ }^{\circ}$ de Engenharia Agrícola, Universidade Federal de Viçosa, UFV, Viçosa, MG, Brasil. E-mail: fernanda.sousa@ufv.br

4 Discente de Doutorado, Dept ${ }^{\circ}$ de Zootecnia, Universidade Federal da Paraíba, UFPB, Areia, PB, Brasil. E-mail: leonardoknupp@ hotmail.com

* Author for correspondence
} 
degradação dos carboidratos não fibrosos (kdCNF) e lag time (Lag). Os alimentos foram agrupados através dos parâmetros de cinética de fermentação ruminal, utilizando-se um $\mathrm{R}^{2}$ de 0,8 , em seis diferentes grupos. A torta de nabo forrageiro e os farelo de algodão, soja, crambe e girassol compuseram o primeiro grupo, enquanto o segundo grupo foi formado pelas tortas de babaçu e de girassol. O terceiro grupo foi formado por farelo de canudo-de-pito e farelo de mamona destoxificado e pelas tortas de algodão, licuri e pinhão-manso I e II. O quarto grupo apresentou as tortas de amendoim I, crambe e dendê. O grupo cinco apresentou somente a torta de amendoim II, sendo que de forma semelhante o grupo seis foi formado apenas pela torta de macaúba. Os valores de VFCF e VFCNF variaram de 16,72 a 200,07 mL e 53,09 a $242,12 \mathrm{~mL}$, respectivamente. Os valores médios de KdCF e KdCNF variaram de 0,0002 a 0,039 \% $\mathrm{h}^{-1} \mathrm{e}$ 0,022 a $0,430 \% \mathrm{~h}^{-1}$, respectivamente. O Lag médio e o VFT variaram de 0,0001 a 5,2029 h e 136,94 a $301,44 \mathrm{~mL}$. Alguns produtos possuem potencial para substituir o farelo de soja, especialmente a torta de nabo forrageiro e os farelos de algodão, crambe e girassol.

Palavras-chave: Carboidratos fibrosos, carboidratos não fibrosos, ruminantes, taxa de degradação

\section{Introduction}

The oil crisis of the past few decades, along with the demand for fuels and increasing environmental concerns, has placed liquid biofuels (such as biodiesel) in the spotlight as alternative energy sources (ABDALLA et al., 2008; SUAREZ et al., 2009).

It is estimated that by 2030, the use of biofuels in Brazil can reach $8 \%$ of the total fuel used in the transport sector (LOFRANO et al., 2013). Thus, there is a trend toward significant increases in biodiesel production and the availability of byproducts, which will generate opportunities for the ruminant production system (NUNES et al., 2010). This possibility has attracted the interest of many producers. However, the utilization of these nutrients depends on basic knowledge of their chemical-nutritional composition and degradability in the rumen.

Several methods have been adopted to determine the amounts and proportions of nutrients required for optimal microbial and animal responses through predictions of nutrient availability in the rumen (MAGALHÃES et al., 2006). Among these techniques, in vitro digestibility assays predominate.

According to Theodorou et al. (1994), the in vitro gas production technique simulates the ruminal environment. Therefore, this technique makes it possible to study the kinetic parameters of the fractions constituting feeds because it reflects the rate at which the components are fermented by rumen microorganisms and the extent of fermentation (CABRAL et al., 2002). The gas production model considers microbial growth and gas production to occur in the same proportions during consumption of the substrate, generating the by-products $\mathrm{CO}_{2}$, methane and volatile fatty acids (SCHOFIELD et al., 1994).

Based on these observations, the objective was to evaluate the nutritional value of by-products from the biodiesel industry and to determine the best feeds for using in the ruminants diets, through the in vitro gas production technique.

\section{Material and Methods}

\section{Feedstuffs}

The experiments were performed at the Department of Animal Science of the Federal University of Viçosa, located in Viçosa, MG (Brazil).

It were included the following 18 samples of cakes and meals in the analysis, which are by-products of the biodiesel industry exhibiting potential for use in ruminant feeding: Meals of cottonseed (Gossypium spp. L.), canudo-de-pito (Mabea fistulifera Mart), crambe (Crambe abyssinica), sunflower (Helianthus annuus), castor seed (Ricinus communis) detoxified with lime and soybean (Glycine max). Moreover, cakes of cottonseed (Gossypium spp. L.), babassu 
(Orbignya speciosa), crambe (Crambe abyssinica), palm kernel (Elaeis guineensis), sunflower (Helianthus annuus), licuri nut (Syagrus coronata), macauba fruit (Acrocomia aculeata), forage radish (Raphanus sativus), two types of jatropha (Jatropha curcas) and two types of peanut (Arachis hypogaea).

The two different samples of jatropha and peanut cakes, originating from different regions of Brazil, were included because they could potentially result in differences in the chemical-nutritional composition of the diets. Soybean meal was used as the reference (control treatment) for the other feeds.

\section{Chemical analyses and calculations}

To quantify the indigestible neutral detergent fiber (iNDF), the samples were processed in a Wiley knife mill equipped with $2 \mathrm{~mm}$ sieves. For the other analyses and in vitro incubation, a portion of each sample was ground in a $1 \mathrm{~mm}$ sieve.
It was quantified the dry matter (DM) (Method 930.15), mineral matter (MM) (Method 942.05) and crude protein (CP) (Method 984.13) in accordance with the methods described by AOAC (1995) (Table 1). Neutral detergent fiber (Method INCTCA F-002/1) corrected for residual ash (Method INCT-CA M-002/1) and protein (Method INCT-CA $\mathrm{N}-004 / 1)$ (NDFap) and lignin (Method INCT-CA F-005/1) contents were quantified in accordance with the methods described by Detmann et al. (2012). To evaluate the ether extract (EE) content, the by-products were conditioned in XT4 (Ankom Technology Corp., Macedon, NY, USA) bags and subjected to excretion using the official AOCS hightemperature (AOCS, 2009) method using an XT15 extractor (Ankom Technology Corp., Macedon, NY, USA). The starch content was quantified using a modified amyloglucosidase/ $\alpha$-amylase enzymatic method (McCLEARY et al., 1997).

Table 1. Average of the chemical composition of the feeds $(n=3)$.

\begin{tabular}{lccccccccc}
\hline & \multicolumn{7}{c}{$\begin{array}{c}\mathrm{DM} \\
\end{array}$} & \multicolumn{7}{c}{$\mathrm{g} \mathrm{kg}^{-1}$ of the DM } \\
\cline { 3 - 9 } & OM & CP & EE & NDFap & NFC & Lignin & Starch & iNDF \\
\hline Cottonseed meal & 876.1 & 919.2 & 541.4 & 21.0 & 232.7 & 124.0 & 27.5 & 18.3 & 188.5 \\
Canudo de pito meal & 890.2 & 923.0 & 577.5 & 31.5 & 101.3 & 212.7 & 21.1 & 7.0 & 51.1 \\
Crambe meal & 845.9 & 915.6 & 431.1 & 5.6 & 357.7 & 121.2 & 31.2 & 21.3 & 218.7 \\
Sunflower meal & 898.1 & 937.8 & 277.7 & 10.6 & 485.9 & 163.6 & 36.1 & 25.9 & 286.1 \\
Castor seed meal & 886.7 & 819.5 & 353.2 & 26.6 & 326.2 & 113.5 & 19.7 & 24.5 & 319.8 \\
Soybean meal & 889.0 & 931.5 & 492.0 & 10.0 & 150.7 & 278.8 & 11.9 & 145.0 & 10.5 \\
Macauba fruit cake & 896.5 & 948.5 & 373.1 & 86.6 & 449.1 & 39.7 & 35.1 & 19.3 & 121.3 \\
Cottonseed cake & 915.8 & 948.6 & 313.7 & 93.1 & 469.6 & 72.2 & 33.9 & 8.7 & 234.8 \\
Peanut cake I & 887.1 & 948.7 & 520.2 & 51.8 & 152.6 & 224.1 & 13.8 & 27.8 & 60.5 \\
Peanut cake II & 921.7 & 920.0 & 429.7 & 151.4 & 127.5 & 211.4 & 25.6 & 58.0 & 46.4 \\
Babassu cake & 932.0 & 944.5 & 190.6 & 92.0 & 623.0 & 38.9 & 42.2 & 10.3 & 407.1 \\
Crambe cake & 863.7 & 920.6 & 326.1 & 184.0 & 276.4 & 134.0 & 30.6 & 7.6 & 189.5 \\
Palm kernel cake & 894.1 & 924.4 & 196.0 & 53.7 & 601.0 & 73.6 & 50.4 & 16.1 & 227.5 \\
Sunflower cake & 884.1 & 934.1 & 287.8 & 21.1 & 390.0 & 235.2 & 37.4 & 8.5 & 247.5 \\
Licuri nut cake & 933.0 & 954.1 & 189.2 & 165.9 & 521.8 & 77.2 & 37.8 & 18.9 & 350.6 \\
Forage radish cake & 917.2 & 930.3 & 374.5 & 138.9 & 153.7 & 263.2 & 33.5 & 19.6 & 98.7 \\
Jatropha cake I & 919.1 & 932.2 & 253.2 & 133.8 & 422.2 & 122.9 & 40.9 & 9.9 & 347.1 \\
Jatropha cake II & 919.2 & 930.2 & 283.5 & 86.7 & 433.1 & 126.9 & 43.2 & 10.9 & 400.8 \\
\hline
\end{tabular}

$\mathrm{DM}=$ dry matter; $\mathrm{OM}=$ organic matter; $\mathrm{CP}=$ crude protein; $\mathrm{EE}=$ ether extract; NDFap = neutral detergent fiber corrected for residual ash and protein; NFC $=$ non-fibrous carbohydrates; iNDF $=$ undegradable neutral detergent fibrous. 
The iNDF was estimated through in situ incubation for 240 hours in a rumen-fistulated bull, in accordance with the procedures described by Casali et al. (2008).

To calculate non-fibrous carbohydrates (NFC), we adopted the equation proposed by Detmann and Valadares Filho (2010):

$$
\mathrm{NFC}=\mathrm{OM}-\left(\mathrm{CP}+\mathrm{EE}+\mathrm{NDF}_{\mathrm{ap}}\right)
$$

where: NFC = non-fibrous carbohydrates $\left(\mathrm{g} \mathrm{kg}^{-1}\right)$; $\mathrm{OM}=$ organic matter $\left(\mathrm{g} \mathrm{kg}^{-1}\right) \mathrm{CP}=$ crude protein $(\mathrm{g}$ $\left.\mathrm{kg}^{-1}\right) ; \mathrm{EE}=$ ether extract $\left(\mathrm{g} \mathrm{kg}^{-1}\right) ; \mathrm{NDF}_{\text {ap }}=$ neutral detergente fiber corrected for ash and protein $\left(\mathrm{g} \mathrm{kg}^{-1}\right)$.

\section{Simulation of rumen degradation}

To calculate the accumulated gas production three replicates of each sample, weighing approximately $200 \mathrm{mg}$ each, were examined. The samples were introduced into graduated glass syringes (HÃBERLE Labortechnik, FORTUNA ${ }^{\circledR}$ Germany) that had previously been washed and dried in an oven, in which the plunger was lubricated with liquid petroleum jelly.

During the incubation process, it was used a solution containing four parts of McDougall's buffer (McDOUGAL, 1949), adjusted to $\mathrm{pH}$ 6.8 (previously adjusted via $\mathrm{CO}_{2}$ sparging for approximately 30 minutes), and one part of rumen fluid. The rumen fluid was collected from 3 rumenfistulated crossbred steers that had been fed on a combination of corn silage and a concentrate mixture in a 60:40 forage-to-concentrate ratio. The fluid was conditioned into three thermal containers (temperature previously regulated to $39^{\circ} \mathrm{C}$ ) and taken to the laboratory. The rumen fluid collected from the three steers was mixed and filtered through a double layer of gauze prior to adding to the McDougall's buffer, as described above. The syringes were filled with $20 \mathrm{~mL}$ of the final solution and placed on an orbital shaking platform for conditioning in a temperature-controlled room at $39^{\circ} \mathrm{C}$.
Gas production readings were performed at 1, $2,3,4,5,6,8,10,12,15,24,27,30,33,36,48$, $56,60,72,96$ and 120 hours after the beginning of incubation by directly analyzing the displacement of the syringe plunger.

\section{Statistical analysis}

The gas production curves were adjusted to the two-compartment model described by Schofield et al. (1994):

$$
\mathrm{Vt}=\mathrm{Vf} f_{1} \times\left\{1+\mathrm{e}^{\left[2+4 \times \frac{\mu \mathrm{m}_{1}}{\mathrm{Vf}_{1}} \times(\mathrm{L}-\mathrm{t})\right]}\right\}^{-1}+\mathrm{Vf}_{2} \times\left\{1+\mathrm{e}^{\left[2+4 \times \frac{\mu \mathrm{m}_{2}}{\mathrm{Vf}_{2}} \times(\mathrm{L}-\mathrm{t})\right]}\right\}^{-1},
$$

where: $\mathrm{Vt}=$ final gas volume $(\mathrm{mL}) ; \mathrm{Vf}_{1}=$ final gas volume produced from non-fibrous carbohydrates $(\mathrm{mL}) ; \mu \mathrm{m}_{1}=$ maximum gas production rate of nonfibrous carbohydrates $\left(\mathrm{mL} \mathrm{h}^{-1}\right) ; \mathrm{L}=$ lag time (hours); $\mathrm{t}=$ time since the beginning of incubation (hours); $\mathrm{Vf}_{2}=$ final gas volume produced from fibrous carbohydrates $(\mathrm{mL})$; and $\mu \mathrm{m}_{2}=$ maximum gas production rate of fibrous carbohydrates $\left(\mathrm{mL} \mathrm{h}^{-1}\right)$.

According to Schofield et al. (1994), the $\mu \mathrm{m} / \mathrm{Vf}$ ratio corresponds to the specific digestion rate $(\mathrm{k})$ of the substrate, which is accepted as being equivalent to the microbial growth rate, given that the gas volume produced, microbial growth and digestion of the substrate are directly proportional.

Subsequently, the feeds were grouped according to their ruminal fermentation kinetics via Ward's minimum-variance method (WARD, 1963) using SAS software (SAS INSTITUTE INC, 2008).

\section{Results and Discussion}

\section{Cluster analysis}

The cluster analysis performed on the kinetic parameters, total gas production (VfT), gas production from fibrous carbohydrates (VfFC), gas production from non-fibrous carbohydrates (VfNFC), the degradation rate of fibrous 
carbohydrates $(\mathrm{kdFC})$, the degradation rate of non-fibrous carbohydrates (kdNFC) and lag time (lag), suggested the formation of up to 17 different groups of feeds (Figure 1). However, such dispersed clustering is not interesting from a practical standpoint because it groups only feeds that exhibit an almost equal rumen degradation pattern. Therefore, we set a maximum $\mathrm{R}^{2}$ value of 0.80 for the analysis and the feeds were grouped into six main groups, as follow: Forage radish cake and the meals of cottonseed, soybean, crambe and sunflower composed the first group, while the cakes of babassu and sunflower formed the second group. Canudo de pito and castor seed meals and the cakes of cottonseed, licuri and jatropha I and II formed the third group. The fourth group was composed by the cakes of crambe, palm kernel and peanut I. The fifth group was formed by peanut cake II, while macauba fruit cake formed the sixth group. This way, there were formed groups with a high similarity $(80 \%)$ between feeds and it was avoided forming an excessive number of groups that could compromise the usability of the results.

Thus, the feeds examined in this study were clustered to increase the variability between groups and to reduce the variability within each group, thereby forming groups containing feeds that represented potential replacements for each other.

\section{Gas production}

Group I was formed by five feeds and was characterized by high VfNFC and VfFC values (Table 2). The gas volume produced from nonfibrous carbohydrates was $116.04 \mathrm{~mL}$ on average, showing variation within the group, ranging from 81.72 to $139.57 \mathrm{~mL}$, for cottonseed meal and soybean meal, respectively. The fermentation of NFC begins immediately after incubation and displays an almost-complete and constant availability among feeds (VAN SOEST, 1967; MERTENS, 1996). Thus the variation in VfNFC observed might have been caused by the NFC content of the feeds in this group, which ranged from 124.0 to $278.8 \mathrm{~g} \mathrm{~kg}^{-1}$ (Table 1).

The average gas production from fibrous carbohydrates recorded in group I was 136.40 $\mathrm{mL}$, varying from 119.00 to 161.87 , for sunflower meal and soybean meal, respectively. Regarding VfFC, although soybean meal exhibited the greatest degradation of the fibrous fraction among the feeds in group I, it exhibited the lowest NDF content $\left(150.7 \mathrm{~g} \mathrm{~kg}^{-1}\right)$. Sunflower meal, in turn, exhibited the highest NDF content among the feeds in this group (485.9 $\mathrm{g} \mathrm{kg}^{-1}$ ), but the degradability of FC was the lowest. This can be explained by the content of lignin that is completely non-degradable and forms a barrier that stops microorganisms from accessing potentially degradable components of the NDF fraction (FREITAS et al., 2006; MIZUBUTI et al., 2011).

The observed degradation rates ranged from 0.053 to 0.126 and 0.012 to $0.039 \% \mathrm{~h}^{-1}$, for nonfibrous and fibrous carbohydrates, respectively. The lag values varied from 0.0011 to 1.4708 hours, for sunflower meal and forage radish cake, respectively. The EE content of forage radish cake $\left(138.9 \mathrm{~g} \mathrm{~kg}^{-}\right.$ 1; the highest of the group) was possible the factor that delayed the colonization of the fibrous fraction by microorganisms, represented by the higher lag observed (1.4708 hours). It is known that elevated oil contents impair the rumen fermentation of its fiber through various mechanisms, such as physical protection of fiber and the effects of surfactants on microorganism membranes (BYERS; SCHELLING, 1988).

Group II was conspicuous by its low NFC degradation rate, with an average $41.78 \mathrm{~mL}$ of gas produced being produced from this fraction. The volume of gas originating from the degradation of the fibrous fraction of the feeds was $139.58 \mathrm{~mL}$ in this group on average. The large volume of gases produced from the degradation of NDF presented by the feeds was linked to the high average NDF content of these feeds coupled with their low NFC content, especially for babassu cake (Table 1). 
Figure 1. Grouping of foods according to their degradability in vitro, using rumen kinetics parameters for the cluster analysis.

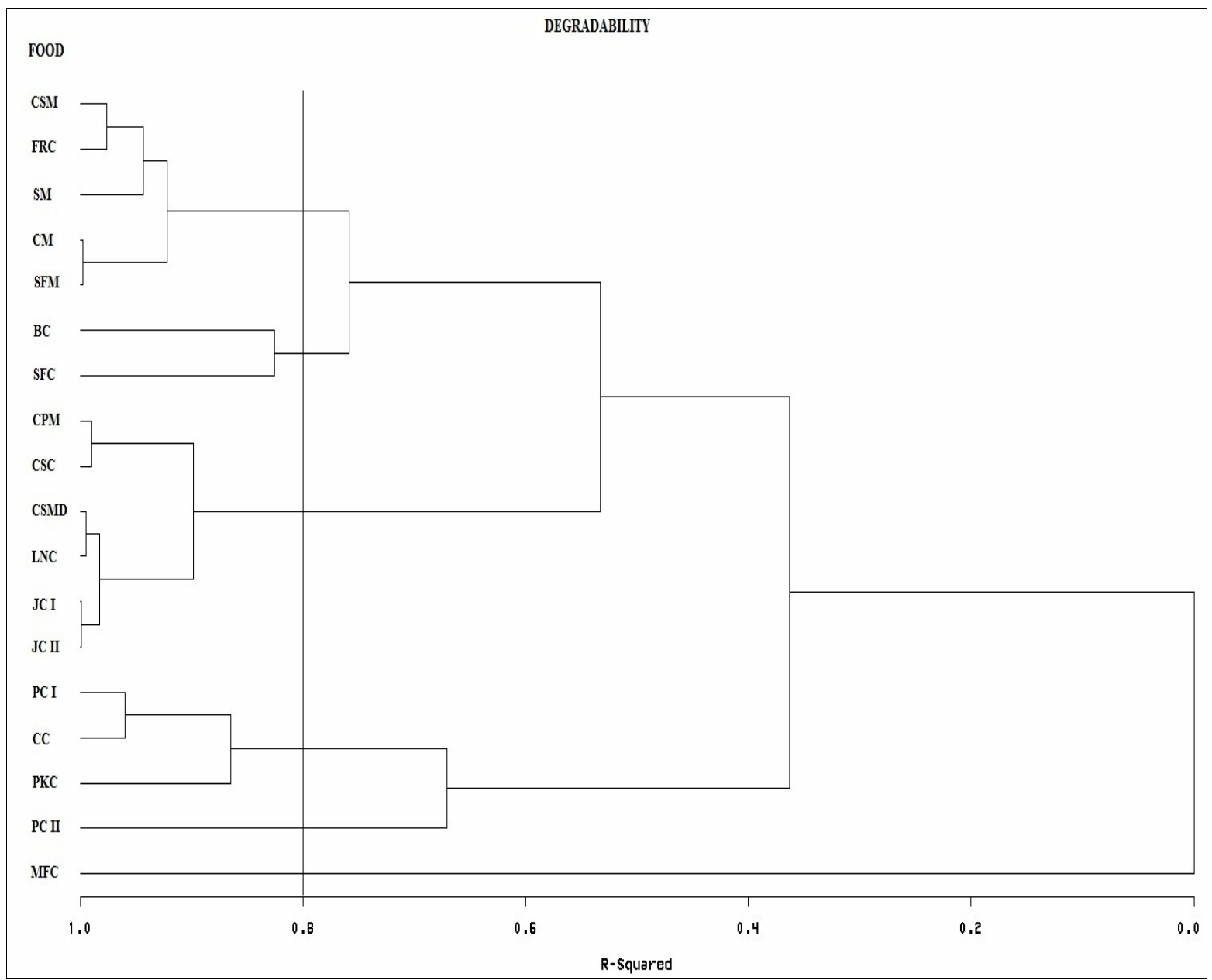

$\mathrm{CSM}=$ Cottonseed meal; $\mathrm{FRC}=$ forage radish cake; $\mathrm{SM}=$ soybean meal; $\mathrm{CM}=$ crambe meal; $\mathrm{SFM}=$ sunflower meal; $\mathrm{BC}=\mathrm{babassu}$ cake; $\mathrm{SFC}=$ sunflower cake; $\mathrm{CPM}=$ canudo de pito meal; $\mathrm{CSC}=$ cottonseed cake; $\mathrm{CSMD}=$ castor seed meal detoxified; $\mathrm{LNC}=$ licuri nut cake; JC I= jatropha cake I; JC II= jatropha cake II; PC I= peanut cake I; CC= crambe cake; $\mathrm{PKC}=$ palm kernel cake; $\mathrm{PC}$ II= peanut cake II; $\mathrm{MFC}=$ macauba fruit cake. 
Table 2. Kinetic parameters related to rumen degradation $(n=3)$.

\begin{tabular}{|c|c|c|c|c|c|c|c|}
\hline Group & Food & VfNFC $^{1}$ & $\mathrm{kdNFC}^{2}$ & $\mathrm{Lag}^{3}$ & $\mathrm{VfFC}^{4}$ & $\mathrm{kdFC}^{5}$ & $\mathrm{VfT}^{6}$ \\
\hline \multirow{6}{*}{ Group I } & Cottonseed meal & 81.72 & 0.053 & 0.0048 & 150.34 & 0.012 & 232.06 \\
\hline & Forage radish cake & 97.99 & 0.126 & 1.4708 & 130.10 & 0.039 & 228.09 \\
\hline & Soybean meal & 139.57 & 0.103 & 1.0137 & 161.87 & 0.023 & 301.44 \\
\hline & Crambe meal & 127.54 & 0.068 & 0.6611 & 120.68 & 0.020 & 248.22 \\
\hline & Sunflower meal & 133.39 & 0.101 & 0.0011 & 119.00 & 0.020 & 252.39 \\
\hline & Average values & 116.04 & 0.090 & 0.6303 & 136.39 & 0.0228 & 252.44 \\
\hline \multirow{3}{*}{ Group II } & Babassu cake & 26.83 & 0.298 & 0.0032 & 177.28 & 0.035 & 204.11 \\
\hline & Sunflower cake & 56.74 & 0.064 & 2.2446 & 101.87 & 0.023 & 158.61 \\
\hline & Average values & 41.78 & 0.181 & 1.1239 & 139.57 & 0.029 & 181.36 \\
\hline \multirow{7}{*}{ Group III } & Canudo de pito meal & 99.71 & 0.082 & 0.0323 & 64.89 & 0.016 & 164.60 \\
\hline & Cottonseed cake & 110.62 & 0.117 & 0.0001 & 91.28 & 0.019 & 201.90 \\
\hline & Castor seed meal detoxified & 71.37 & 0.072 & 0.0030 & 96.53 & 0.015 & 167.90 \\
\hline & Licuri nut cake & 51.01 & 0.065 & 0.0025 & 112.38 & 0.002 & 163.39 \\
\hline & Jatropha cake I & 59.24 & 0.101 & 0.5380 & 77.70 & 0.024 & 136.94 \\
\hline & Jatropha cake II & 55.77 & 0.087 & 0.2633 & 85.39 & 0.024 & 141.16 \\
\hline & Average values & 74.62 & 0.087 & 0.1398 & 88.03 & 0.016 & 162.65 \\
\hline \multirow{4}{*}{ Group IV } & Peanut cake I & 157.46 & 0.073 & 2.6039 & 91.64 & 0.012 & 249.10 \\
\hline & Crambe cake & 126.84 & 0.073 & 1.9857 & 53.54 & 0.018 & 180.38 \\
\hline & Palm kernel cake & 170.13 & 0.022 & 5.2029 & 53.09 & 0.010 & 223.22 \\
\hline & Average values & 151.47 & 0.056 & 3.2641 & 66.09 & 0.013 & 217.56 \\
\hline Group V & Peanut cake II & 200.07 & 0.109 & 0.0005 & 63.07 & 0.019 & 263.14 \\
\hline Group VI & Macauba fruit cake & 16.72 & 0.430 & 2.8484 & 242.12 & 0.034 & 258.84 \\
\hline
\end{tabular}

The high NDF contents determined made it possible to use these feeds as substitutes for various roughages based on their rumen fermentation kinetics. For example, when using babassu cake as a replacement for sugarcane in the diets of heifers at rates of 0,10, 20 and 30\%, Castro (2012) did not observe alterations in dry matter intake or NDF intake. Considering the data obtained in this study, which are consistent with the data reported in the literature, we can infer that based on the observed rumen fermentation kinetics, the feeds from group II presented greater potential as replacements for roughage feeds in the ruminant diet.

The mean degradation rates for $\mathrm{NFC}$ and fibrous carbohydrates (FC) were 0.181 and $0.03 \%$ $\mathrm{h}^{-1}$, respectively. The average lag for this group was higher than for group I, at 1.1239 hours. The degradation rates for group II were higher than for group I and the difference in lag time observed between groups I and II was likely due to the EE content of the feeds in group II, which was higher than the majority of feeds from group I, making it difficult for the ruminal microorganisms to colonize the fibrous fraction (Table 1).

Group III was composed of six feeds and was characterized by intermediate VfNFC and VfFC values compared to the other groups. The average gas production from non-fibrous carbohydrates was $74.63 \mathrm{~mL}$, varying between 51.01 and 110.62 for the licuri nut and cottonseed cakes, respectively. The gas production from fibrous carbohydrates was $88.03 \mathrm{~mL}$, on average, varying between 64.89 and $112.38 \mathrm{~mL}$ for canudo de pito meal and licuri nut cake, respectively. Feeds from group III demonstrated high lignin contents, reflected in the great participation of non-degradable fiber in the NDF (Table 1). Because lignin is undegradable and reduces the degradation of the potentially 
degradable fraction, it is accepted as the main factor responsible for limiting the degradation of the NDF fraction (VAN SOEST, 1994; CASSIDA et al., 2007; MIZUBUTI et al., 2011).

The degradation rates observed for fibrous and non-fibrous carbohydrates in this group were lower than in groups I and II, and the average $\mathrm{kdNFC}$ and $\mathrm{kdFC}$ values were 0.088 and $0.016 \%$ $\mathrm{h}^{-1}$, respectively. Feeds with a low degradation rate, such as those in group III, are highly dependent on the passage rate for their use by ruminal microorganisms to be increased. The rumen fill effect caused by concentrate feeds is not as evident as that resulting from roughage feeds because roughage feeds exhibit a higher NDF content and physicochemical characteristics that lead to lower degradation of this fraction (OLIVEIRA et al., 2011). However, when the composition of the feeds in this group was analyzed, with the exception of canudo de pinto meal, we observed elevated NDFap values (Table 1), which may have caused the similar behavior of the feeds in this group compared to certain types of roughage feeds.

Considering the values corresponding to the degradation of both carbohydrate fractions and the broad variation of responses found in the literature for the feeds of group III (VIEIRA et al., 2010; SILVA et al., 2011), we can infer that these feeds should be used in animals involved in low or intermediate production levels, and that they are not good choices for diets with a high level of concentrate inclusion, in which the goal is increased escape of nutrients for digestion and absorption in the small intestine. The low degradation rates demonstrated by these feeds would result in a lower dry matter intake, possibly compromising animal performance.

Group IV exhibited high VfNFC values and intermediate $\mathrm{VfFC}$ values, at 151.48 and $66.09 \mathrm{~mL}$, respectively. The gas production from non-fibrous carbohydrates varied from 126.84 to $170.13 \mathrm{~mL}$ in this group, for crambe and palm kernel cakes, respectively. However, the gas production from fibrous carbohydrates varied from 53.09 to $91.64 \mathrm{~mL}$ for palm kernel cake and peanut cake I, respectively. The palm kernel cake exhibiting the highest NDF of the group IV (60.10\%), and is also rich in lignin $\left(50.4 \mathrm{~g} \mathrm{~kg}^{-1}\right)$, which might have limited the utilization of its fibrous fraction by the microorganisms. The opposite situation was observed for peanut cake I, which exhibited low lignin content (13.8 $\left.\mathrm{g} \mathrm{kg}^{-1}\right)$. Crambe cake demonstrated a VfFC value similar to that of palm kernel cake; however, in this case, the factor that might have limited the degradation of the fibrous fraction was the high EE content of the crambe cake compared with palm kernel (184.0 vs. $\left.53.7 \mathrm{~g} \mathrm{~kg}^{-1}\right)$.

The average degradation rates were 0.056 and $0.13 \% \mathrm{~h}^{-1}$ for NFC and FC, respectively. The average lag time for the group was 3.2641 hours, which was the highest value obtained among the studied groups. Palm kernel cake demonstrated high NDFap and lignin contents (60.10 and 5.04\%, respectively). Therefore, palm kernel cake represents a difficultto-degrade matrix, resulting in a low $\mathrm{kdCF}(0.010 \%$ $\left.\mathrm{h}^{-1}\right)$. The poor degradation of the fibrous fraction coupled with the low NFC content $\left(73.6 \mathrm{~g} \mathrm{~kg}^{-1}\right)$ may result in lower ruminal energy availability and, thus, decreased animal performance as was observed by Silva et al. (2012).

The feed that contributed most to increasing the lag time was palm kernel cake, which resulted in a lag of 5.2029 hours. Although this feed did not exhibit a high EE content $\left(53.7 \mathrm{~g} \mathrm{~kg}^{-1}\right)$, palm kernel cake is rich in lignin $\left(50.4 \mathrm{~g} \mathrm{~kg}^{-1}\right)$, which might have contributed to the high lag value observed.

Group V was composed of only peanut cake II and was characterized by an elevated VfNFC (200.07 mL). It was expected that Peanut cake II should demonstrate behavior similar to peanut cake I. However, the variation between these byproducts, which is caused by de-standardization of the processing systems that produced the two seed samples, coupled with the dependence on the variety planted, produces differences in the 
chemical-nutritional composition of the feeds and, consequently, rumen degradability (GOES et al., 2010).

The high starch content of peanut cake II (58.0 $\mathrm{g} \mathrm{kg}^{-1}$ ) might have positively influenced the gas production from its NFC fraction compared to the other feeds. The low VfFC observed for this feed type, especially compared to peanut cake I, is a reflection of its lower NDF content coupled with the greater participation of lignin in the fibrous fraction $\left(25.6 \mathrm{~g} \mathrm{~kg}^{-1}\right)$.

Group VI was also composed of a single feed type, Macauba fruit cake. And it was characterized by a lowest gas volume produced from the NFC fraction $(16.72 \mathrm{~mL})$, and a greatest gas volume from the fibrous fraction $(242.12 \mathrm{~mL})$.

Apparently, the low VfNFC observed for Macauba fruit cake, in group VI, coupled with its high VfFC, was caused by its low NFC content (39.7 $\mathrm{g} \mathrm{kg}^{-1}$ ). In addition to limiting microbial growth from this substrate, this low NFC content also stimulated increased digestion of NDF because it caused the $\mathrm{pH}$ to decrease. This fact, coupled with the high NDF content observed (449.1 $\mathrm{g} \mathrm{kg}^{-1}$ ), was likely the cause of the high VfFC obtained for this feed type.

The lag recorded for this feed was the second highest among all of groups. This result can be explained by its high EE content (86.6 $\mathrm{g} \mathrm{kg}^{-1}$ ) combined with its high lignin content $\left(35.1 \mathrm{~g} \mathrm{~kg}^{-}\right.$ $\left.{ }^{1}\right)$, which together, can retard colonization of the fibrous fraction by the microorganisms.

\section{Conclusions}

Soybean meal displayed the best properties in relation to potential inclusion in the diets of animals. However, a number of the investigated feeds, such as the cottonseed, crambe and sunflower meals as well as forage radish cake, exhibited useful qualities. Therefore, these feeds should be further investigated using in vivo experiments to establish whether they can be used in the ruminant diet and to determine the ideal levels for their inclusion.

\section{Acknowledgments}

The authors thank the sponsors, CNPq, CAPES, FAPEMIG and INCT-CA.

\section{References}

ABDALLA, A. L.; SILVA FILHO, J. C. da; GODOI, A. R. de; CARMO, C. D. A.; EDUARDO, J. L. de P. Utilização de subprodutos da indústria de biodiesel na alimentação de ruminantes. Revista Brasileira de Zootecnia, Viçosa, MG, v. 37, p. 260-268, 2008. Suplemento Especial.

ASSOCIATION OF OFFICIAL ANALYTICAL CHEMISTS - AOAC. Official methods of analysis. $16^{\text {th }}$ ed. Arlington, VA: Association of Official Analysis Chemists, 1995. 2000 p.

AMERICAN OIL CHEMISTS SOCIETY - AOCS. Rapid determination of oil/fat utilizing high temperature solvent extraction. Urbana, IL: American Oil Chemists Society, 2009. Available at: <http://www.ankom. com/media/documents/CrudeFat_0504_013009.pdf>. Accessed at: 20 jan. 2014.

BYERS, F. M.; SCHELLING, G. Los lípidos en la nutrición de los rumiantes. In: CHURCH, D. C. $E l$ rumiante: fisiolog ia digestiva y nutrición. Zaragoza: Acribia Press, 1988. p. 339-356.

CABRAL, L. S.; VALADARES FILHO, S. C.; DETMANN, E.; ZERVOUDAKIS, T. J.; PEREIRA, O. G.; GONÇALVES VELOSO, R.; PEREIRA, E. S. Cinética ruminal das frações de carboidratos, produção de gás, digestibilidade in vitro da matéria seca e NDT estimado da silagem de milho com diferentes proporções de grãos. Revista Brasileira de Zootecnia, Viçosa, MG, v. 31, n. 6, p. 2332-2339, 2002.

CASALI, A. O.; DETMANN, E.; VALADARES FILHO, S. C.; PEREIRA, J. C.; HENRIQUES, L. T.; FREITAS, S. G.; PAULINO, M. F. Influência do tempo de incubação e do tamanho de partículas sobre os teores de compostos indigestíveis em alimentos e fezes bovinas obtidos por procedimentos in situ. Revista Brasileira de Zootecnia, Viçosa, MG, v. 37, n. 2, p. 335-342, 2008.

CASSIDA, K. A.; TURNER, K. E. E.; FOSTER, J. G. G.; HESTERMAN, O. B. Comparison of detergent fiber analysis methods for forages high in pectin. Animal Feed Science and Technology, Amsterdam, v. 135, n. 3-4, p. 283-295, 2007. 
CASTRO, K. J. Torta de babaçu: consumo, digestibilidade, desempenho, energia metabolizável, energia líquida e produção de metano em ruminantes. 2012. Tese (Doutorado em Zootecnia) - Universidade Federal de Minas Gerais, Belo Horizonte.

DETMANN, E.; SOUZA, M. A.; VALADARES FILHO, S. C. Métodos para análises de alimentos. Visconde do Rio Branco: Suprema, 2012. 214 p.

DETMANN, E.; VALADARES FILHO, S. C. On the estimation of non-fibrous carbohydrates in feeds and diets. Arquivo Brasileiro de Medicina Veterinária e Zootecnia, Belo Horizonte, v. 62, n. 4, p. 980-984, 2010.

FREITAS, A. W. P.; PEREIRA, J. C.; ROCHA, F. C. Avaliação da divergência nutricional de genótipos de cana-de-açúcar (Saccharum ssp.). Revista Brasileira de Zootecnia, Viçosa, MG, v. 35, n. 1, p. 229-236, 2006.

GOES, R. H. T. E. B.; SOUZA, K. A.; PATUSSI, R. A.; CORNELIO, T. D. C.; OLIVEIRA, E. R.; BRABES, K. C. D. S. Degradabilidade in situ dos grãos de crambe, girassol e soja, e de seus coprodutos em ovinos. Acta Scientiarum. Animal Sciences, Maringá, v. 32, n. 3, p. 271-277, 2010

LOFRANO, R. C. Z.; COSTA, F. M. F.; OLIVEIRA, L. A. F.; OLIVEIRA, M. C. A. Métodos e perspectivas tecnológicas de obtenção de biocombustíveis de primeira e segunda geração. E-xacta, Belo Horizonte, v. 6, n. 1, p. 35-53, 2013.

MAGALHÃES, R. T.; GONÇALVES, L. C.; MAURÍCIO, R. M.; RODRIGUES, J. A. S.; BORGES, I.; RODRIGUES, N. M.; SALIBA, E. O. S. Avaliação de quatro genótipos de sorgo pela técnica "in vitro" semiautomática de produção de gases. Revista Brasileira de Milho e Sorgo, Sete Lagoas, v. 5, n. 1, p. 101-111, 2006.

MCCLEARY, B. V.; GIBSON, T. S.; MUGFORD, D. C. Measurement of total starch in cereal products by amyloglucosidase $-\alpha$-amylase method: collaborative study. Journal of Association of Analytical Communities International, Gaithersburg, v. 80, n. 3, p. 571-579, 1997.

MCDOUGAL, E. Studies on ruminal saliva. 1. The composition and output of sheep's saliva. Biochemical Journal, London, v. 46, n. 1, p. 99-109, 1949.

MERTENS, D. Using fiber and carbohydrate analyses to formulate dairy rations. In: INFORMATIONAL CONFERENCE WITH DAIRY AND FORAGE INDUSTRIES, 1996, Winconsin. Proceedings... Winconsin: [s. n.], 1996. p. 81-92.

MIZUBUTI, I. Y.; RIBEIRO, E. L. D. A.; PEREIRA, E. S.; PINTO, A. P.; FRANCO, A. L. C.; SYPERRECK, M. A.; DOREA, J. R. R.; CUNHA, G. E.; CAPELARI, M. G. M.; MUNIZ, E. B. Cinética de fermentação ruminal in vitro de alguns co-produtos gerados na cadeia produtiva do biodiesel pela técnica de produção de gás. Semina: Ciências Agrárias, Londrina, v. 32, n. 4, p. 2021-2028, 2011. Sup1emento.

NUNES, A. S.; OLIVEIRA, R. L.; AYRES, M. C. C.; BAGALDO, A. R.; GARCEZ NETO, A. F.; BARBOSA, L.P. Condição hepática de cordeiros mantidos com dietas contendo torta de dendê proveniente da produção de biodiesel. Revista Brasileira de Zootecnia, Viçosa, MG, v. 39, n. 8, p. 1825-1831, 2010.

OLIVEIRA, A. S.; DETMANN, E.; CAMPOS, J. M. S.; PINA, D. S.; SOUZA, S. M.; GERALDO, C. M.; COSTA, M.G. Meta-análise do impacto da fibra em detergente neutro sobre o consumo, a digestibilidade e o desempenho de vacas leiteiras em lactação. Revista Brasileira de Zootecnia, Viçosa, MG, v. 40, n. 7, p. 1587 1595, 2011.

STATISTICAL ANALYSIS SYSTEM - SAS. Statistical analysis system user's guide: stat, version 9.2. Carry: SAS Institute, 2008.

SCHOFIELD, P.; PITT, R. E.; PELL, A. N. Kinetics of fiber digestion from in vitro gas production. Journal of Animal Science, Champaign, v. 72, n. 11, p. 2980-2991, 1994.

SILVA, D. C.; ALVES, A. A.; OLIVEIRA, M. E.; MOREIRA FILHO, M. A.; RODRIGUES, M. M.; VALE, G. E. S.; NASCIMENTO, H. T. S. Consumo e digestibilidade de dietas contendo farelo de mamona destoxificado para ovinos em terminação. Revista Brasileira de Saúde e Produção Animal, Salvador, v. 12, n. 1, p. 96-106, 2011.

SILVA, R. L. N. V.; OLIVEIRA, R. L.; CARVALHO, G. G. P.; RIBEIRO, O. L.; LEÃO, A. G.; FARIA, M. M. S.; LEDO, C. A. S. Degradabilidade ruminal e balanço energético em vacas leiteiras a pasto suplementadas com torta de dendê. Revista Brasileira de Saúde e Produção Animal, Salvador, v. 13, n. 2, p. 503-515, 2012.

SUAREZ, P. A. Z.; SANTOS, A. L. F.; RODRIGUES, J. Biocombustíveis a partir de óleos e gorduras: desafios tecnológicos para viabilizá-los. Química Nova, São Paulo, v. 32, n. 3, p. 768-775, 2009.

THEODOROU, M. K.; WILLIAMS, B. A.; DHANOA, M. S. A simple gas production method using a pressure transducer to determine the fermentation kinetics of ruminant feeds. Animal Feed Science and Technology, Amsterdam, v. 48, n. 3-4, p. 185-197, 1994.

VAN SOEST, P. J. Development of a comprehensive system of feed analyses and its aplication to forages. Journal of Animal Science, Champaign, v. 2, n. 1, p. 119$128,1967$. 
Nutritional ecology of the ruminant. Ithaca: Cornell University Press, 1994. 476 p.

VIEIRA, M. M. M.; CÂNDIDO, M. J. D.; BOMFIM, M. A. D.; SEVERINO, L. S.; ZAPATA, J. F. F.; BESERRA, L. T.; MENESES, A. J. G.; FERNANDES, J. P. B. Características da carcaça e dos componentes não-carcaça em ovinos alimentados com rações à base de farelo de mamona. Revista Brasileira de Saúde e Produção Animal, Salvador, v. 11, n. 1, p. 140-149, 2010.

WARD, J. H. Hierarchical grouping to optimize an objective function. Journal of American Statistical Association, Washington, v. 58, n. 301, p. 236-244, 1963. 
